\title{
Implementasi Pembelajaran Aktif Berorientasi Mikir (Mengamati, Interaksi, Komunikasi, dan Refleksi) di SD Muhammadiyah 12 Medan
}

\section{Implementation of Active Learning Thinking Oriented (Observing, Interaction, Communication, and Reflection) at SD Muhammadiyah 12 Medan}

\section{Elfrianto $^{1)}$, Ismail Saleh Nasution ${ }^{2)}$, Eko Febriansyah Siregar $^{2)}$ \& Achmad Yuhdi ${ }^{3)}$}

1) Program Studi Pendidikan Matematika, Fakultas Keguruan dan Ilmu Pendidikan, Universitas Muhammdiyah Sumatera Utara, Indonesia

2) Program Studi Pendidikan Guru Sekolah Dasar, Universitas Muhammdiyah Sumatera Utara, Indonesia

3) Program Studi Pendidikan Bahasa dan Sastra Indonesia, Universitas Negeri Medan, Indonesia

Diterima: 27 Juli 2020 ; Disetujui: 27 Agustus 2020 ; Dipublish: 16 September 2020

*Corresponding Email: ismailsalehnst@umsu.ac.id

\begin{abstract}
Abstrak
Kegiatan pengabdian kepada masyarakat ini dilakukan untuk mendampingi guru dalam megelola pembelajaran aktif melalui strategi MIKIR (Mengalami, Interaksi, Komunikasi, dan Refleksi). Mitra kegiatan PKM ini adalah dua sekolah dari antara sekolah-sekolah mitra UMSU, yakni SD Muhammadiyah 12 Medan. Target khusus yang ingin dicapai melalui pelaksanaan kegiatan PKPM ini menghasilkan guru-guru profesional dan terampil dalam mengelola pembelajaran aktif sehingga pembelajaran yang diberikan lebih menarik dan bermakna bagi siswa. Metode pendekatan yang ditawarkan pada kegiatan PKPM ini adalah peatihan dan pendampingan dengan tahapan: 1) Pertemuan awal kepada guru mitra dalam kegiatan persamaan persepsi tentang pembelajaran aktif melalui teknik MIKIR, 2) Pelatihan dan pendampingan secara intensif, 3) praktik di kelas di SD mitra, dan 4) evaluasi hasil kegiatan. Tiap tahapan dilakukan secara maksimal, sehingga kompetensi guru terdamping menjadi lebih baik dalam mengelola pembelajaran aktif yang berorientasi kepada kegiatan MIKIR.

Kata Kunci: pendampingan MIKIR, kompetensi guru, SD Muhammadiyah.
\end{abstract}

\begin{abstract}
This community service activity is carried out to assist teachers in managing active learning through the MIKIR strategy (Experiencing, Interaction, Communication, and Reflection). The PKM activity partners are two schools from among the UMSU partner schools, namely SD Muhammadiyah 12 Medan. Specific targets to be achieved through the implementation of PKPM activities produce professional and skilled teachers in managing active learning so that the learning provided is more interesting and meaningful for students. The approach method offered in this PKPM activity is training and mentoring with stages: 1) Initial meeting to partner teachers in the activity of equality perception about active learning through MIKIR techniques, 2) Intensive training and mentoring, 3) classroom practice in partner elementary schools, and 4) evaluation of the results of activities. Each stage is carried out maximally, so that the competency of the assisted teacher becomes better in managing active learning which is oriented towards MIKIR activities
\end{abstract}

Keywords: MIKIR assistance, teacher competency, Muhammadiyah Elementary School.

How to Cite: Elfrianto, Nasution, I.S \& Siregar, E.F. (2020), Implementasi Pembelajaran Aktif Berorientasi Mikir (Mengamati, Interaksi, Komunikasi, dan Refleksi) di SD Muhammadiyah 12 Medan, Pelita Masyarakat, 2(1): 9-16 


\section{PENDAHULUAN}

Keberhasilan pencapaian kompetensi suatu mata pelajaran oleh guru bergantung kepada beberapa aspek. Salah satu aspek yang sangat mempengaruhi kebehasilan pencapaian kompetensi adalah cara guru dalam melaksanakan pembelajaran. Kecenderungan yang terjadi pada proses pembelajaran di Indonesia adalah kegiatan belajar masih berpusat pada guru, yaitu guru lebih banyak bercerita atau berceramah. Siswa tidak banyak aktif terlibat dalam proses pembelajaran, guru tidak/jarang menggunakan media pembelajaran, sehingga proses pembelajaran menjadi kering dan kurang bermakna. Oleh karena itu paradigma lama di mana orientasi belajar lebih berpusat pada guru harus mulai ditinggalkan dan diganti dengan orientasi belajar lebih berpusat pada siswa atau pembelajaran aktif (Yakob \& Sari, 2019; Setiawan, 2014).

Hasil observasi yang telah dilakukan di dua sekolah yang direncanakan menjadi mitra kegiatan PKPM (Program Kemitraan Pengembangan Muhammadiyah) ini, diperoleh informasi bahwa perangkat perencanaan pembelajaran yang digunakan dalam pelaksanaan pembelajaran di kelas sudah memakai kurikulum 2013 dan sudah digunakan model pembelajaran aktif diantaranya model discovery learning dan inquiry learning, tetapi pada kenyataannya dalam pembelajarannya kurang maksimal dan unsur pembelajaran aktif yang digagas kurikulum 2013 dengan kegiatan 5 M ciri pendekatan saintifik (menanya, mengamati, mencoba, menalar, dan mengkomunikasikan) belum tampak nyata.

Pembelajaran aktif (active learning) adalah istilah umum yang menggambarkan suatu pendekatan pembelajaran yang secara luas diterima di seluruh dunia sebagai praktik terbaik (best practice). Pendekatan ini didasarkan pada prinsip bahwa cara belajar terbaik bagi anak-anak adalah dengan melakukan, dengan menggunakan semua inderanya, dan dengan mengeksplorasi lingkungannya seperti orang, tempat, sesuatu hal, kejadian atau peristiwa yang ada di sekitar kehidupan sehari-hari anak. Mereka harus belajar dari pengalaman langsung dan konkrit (misalnya mengukur luas, menanam bunga, membuat denah, membuat karangan, dan sebagainya) serta berbagai bentuk pengalaman lainnya (misalnya membaca buku, melihat berita di TV, mengunjungi museum). Keterlibatan aktif dengan benda dan gagasan ini mendorong anak aktif berfikir untuk mendapatkan pengetahuan baru dan memadukannya dengan pengetahuan yang sudah dimiliki. 
Keberhasilan suatu kegiatan pembelajaran lebih banyak bergantung kepada kualitas kegiatan-kegiatan yang dilakukan oleh siswa selama pembelajaran berlangsung (Slameto, 2007). Kualitas kegiatan yang dilakukan siswa dapat dilakukan guru dengan melaksanakan proses belajar mengajar menggunakan beberapa model pembelajaran yang inovatif. PAKEM (Pembelajaran Aktif, Kreatif, Efektif, dan Menyenangkan) merupakan pendekatan pembelajaran yang dapat menciptakan lingkungan pembelajaran yang dapat menumbuhkan dan mengembangkan keterampilan, sikap, dan pemahaman siswa (Asmani, 2010). Saat ini pembelajaran siswa aktif tersebut dapat dilakukan menggunakan teknik MIKIR (Mengalamani, Interaksi, Komunikasi, dan Refleksi). Teknik ini diadaptasi dari pelatihan-pelatihan yang dilaksanakan oleh Tanoto Foundation yang telah bermitra dengan UMSU sejak tahun 2017.

Berbagai keberhasilan pembelajaran yang dilakukan guru, setelah menerapkan teknik/strategi pembelajaran dengan konsep MIKIR telah banyak dan dipublikasikan dalam majalah hasil praktik baik dari Tanoto Foundation. Beberapa diantaranya adalah yang dilakukan Juni Hariyanto, guru kelas VI SDN 017976 Air Putih Kab. Batubara. Dalam publikasinya dia menyebutkan bahwa dalam pembelajaran tematik di kelas VI tema 6 tentang menuju masyarakat sehat, dengan subtema 2 yakni masyarakat sehat, menerapkan unsur MIKiR dan menggunakan teknik simulasi kampanye. Pembelajaran ini mengolaborasikan mapel IPS, bahasa Indonesia, dan seni, budaya dan prakarya (SBDP). sehat (PHBS) melalui pembuatan poster.
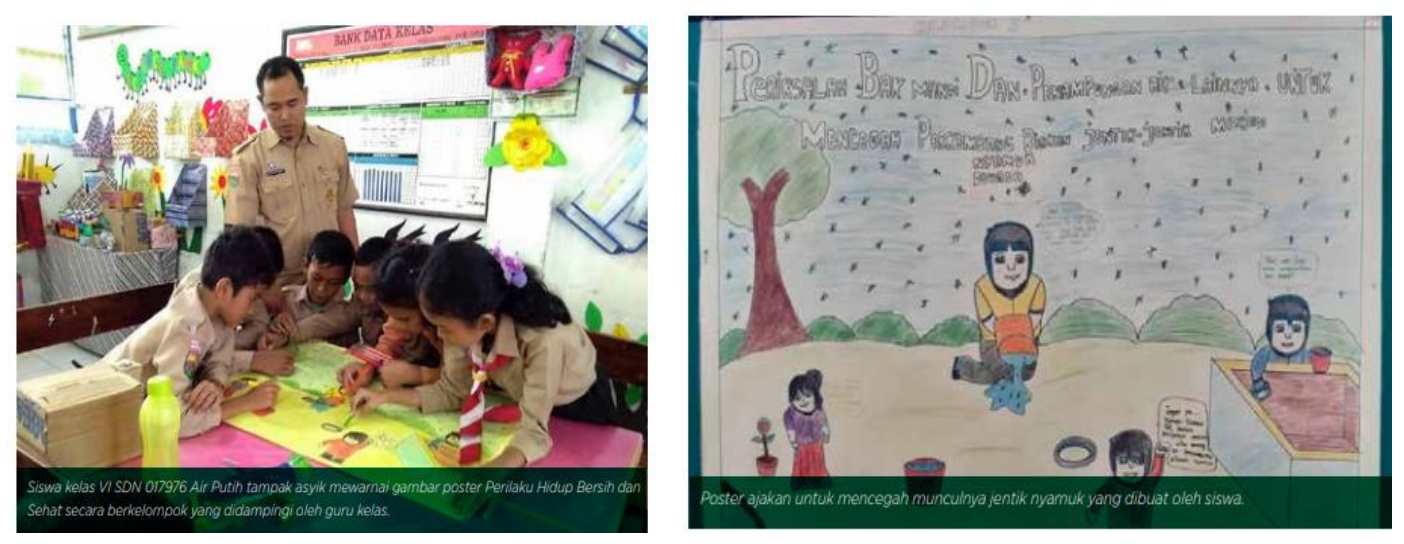

Dua gambar di atas merupakan dokumentasi kegiatan dan hasil kerja siswa setelah pembelajaran selesai dilaksanakan. Dalam praktik baik yang dilakukannya, guru tersebut membagi siswa dalam kelompok. Setiap kelompok terdiri dari enam orang. Mereka ditugaskan membuat sebuah poster dengan memperhatikan langkahlangkah dalam 
pembuatan poster. Mulai dari pemilihan pesan yang sesuai tujuan kampanye PHBS, gambar, bentuk tulisan, dan pewarnaan yang menarik. Setiap kelompok mulai mendiskusikan sebuah pesan utama yang akan mereka tuliskan dalam poster. Beberapa ide muncul dalam diskusi kelompok. Misalnya, mengampanyekan jajanan sehat di kantin sekolah, mengatasi jentikjentik nyamuk, sampai ajakan untuk memelihara kebersihan kuku. Para siswa juga berdiskusi menentukan gambar yang akan dibuat. Setelah disepakati mereka berbagi kerja. Ada yang membuat gambar, ada yang menulis, dan ada yang mewarnai. Setelah poster selesai, kegiatan dilanjutkan dengan mengampanyekan poster dari hasil kerja kelompok. Masing-masing kelompok dapat mengampanyekan dengan melakukan presentasi bersambung yang dijadikan dalam satu kegiatan utuh sehingga menjadi sebuah cerita kolaborasi. "Ayo beli jajanan sehat! Pilihlah makanan yang tidak mengandung bahan pengawet, bahan pewarna, bahan pemanis buatan, dan bahan penyedap agar terhindar dari bahaya keracunan bahan kimia," demikian kampanye kelompok Jajanan Sehat sambal menunjukkan hasil posternya. Kelompok Kesehatan Kuku mengajak teman-temannya memelihara kesehatan kuku dengan cara potonglah kuku minimal satu kali dalam seminggu. Gunakan pemotong kuku dan hindari kebiasaan menggigit kuku. Mereka menggunakan gambar seorang guru yang menasehati seorang siswa untuk memotong kukunya. Sedangkan kelompok Jentik Nyamuk mengampanyekan pentingnya menjaga kebersihan bak mandi. Mereka menggambar empat anak yang sedang melakukan kegiatan 3 M. "Periksalah bak mandi dan penampungan air lainnya untuk mencegah perkembangbiakan jentik-jentik nyamuk menjadi nyamuk dewasa. Caranya dengan 3 M yaitu menguras, mengubur, dan menutup," papar kelompok Jentik Nyamuk. (Program PINTAR, TANOTO FOUNDATION: 2018)

Sekolah yang menjadi tempak kegiatan ini adalah SD Muhammadiyah 12 Medan. Dalam PKPM ini, guru kelas dan/atau guru mapel di sekolah tersebut akan diberi pendampingan pengelolaan pembelajaran aktif berorientasi menggunakan teknik/strategi MIKIR.

\section{ANALISIS SITUASIONAL}

Berdasarkan dasar pemikiran yang dikemukakan di atas, peningkatan profesionalisme guru dalam bidang pengelolaan pembelajaran aktif berorientasi strategi MIKIR saat ini perlu diterapkan. Khususnya, peningkatan kualitas pendidikan tersebut pada sekolah Muhammadiyah yang merupakan bagian dari amal usaha Organisasi 
Muhammadiyah, maka civitas akademika di lingkungan UMSU tentu mempunyai tanggung jawab moral yang besar untuk ikut mengembangkan dan meningkatkan kualitas pembelajaran, yang pada akhirnya akan bermuara kepada peningkatan mutu kualitas lulusan sekolah Muhammadiyah di kota Medan. Berdasarkan analisis situasi yang disebutkan pada poin di atas, fokus permasalahan yang dihadapi sekolah mitra adalah "keterampilan pedagogik guru pada di sekolah mitra yang belum mampu memaksimalkan proses pembelajaran yang berpusat kepada siswa". Permasalahan yang disebutkan itu, melalui kegiatan PKPM ini akan diselesaikan melalui upaya pemberian pelatihan dan pendampingan guru-guru di dua sekolah mitra itu, dalam melakukan PBM dengan menggunakan teknik/strategi pembelajaran aktif menggunakan konsep MIKIR (Mengamati, Interaksi, Komunikasi, dan Refleksi) yang diadaptasi dari program PINTAR Tanoto Faoundation

\section{METODE PELAKSANAAN}

Pelaksanaan program kemitraan masyarakat ini dilakukan dengan tiga tahapan, di mana tahap pertama merupakan tahap persiapan. Pada tahap ini kelompok pengabdian melakukan suvey pendahuluan untuk melihat kondisi di lapangan mengenai sarana dan prasarana serta kompetensi guru di bidang keterampilan melaksanakan pembelajaran (kompetensi pedagogik). Tahap selanjutnya merupakan tahapan pelaksanaan kegiatan program. Dalam tahap ini tim akan melakukan kegiatan pelatihan pembelajaran aktif dilanjutkan dengan kegiatan pendampingan kepada guru-guru yang telah dilatih. Tahap yang terakhir adalah tahap evaluasi. Pada tahap ini dilakukan evaluasi atas hasil yang telah dicapai oleh peserta pelatihan dan pendampingan. Masukan dan perbaikan lebih lanjut dapat dilakukan pada tahap ini. Evaluasi diberikan dengan mengumpulkan data yang diperoleh dari kegiatan pelatihan. Data diambil dengan menyimpulkan pemahaman guru-guru ketika diberikan makalah yang disampaikan dengan metode ceramah dan dilanjutkan dengan tanya jawab/diskusi, serta dari hasil kegiatan yang berwujud aplikasi ujian online masing-masing mata pelajaran yang diampu guru. Indikator ketercapaian tujuan program kemitraan ini adalah bahwa $80 \%$ guru-guru sudah memahami dan dapat membuat dan menerapkan pembelajaran aktif di kelas mereka masing-masing.

\section{HASIL KEGIATAN DAN PEMBAHASAN}

Hasil yang dicapai melalui kegiatan PKM “Pelatihan dan Pendampingan Guru-Guru SD Muhammadiyah 12 Medan dan SD Muhammadiyah 13 Medan dalam Melaksanakan 
Pembelajaran Aktif Berorientasi MIKIR (Mengamati, Interaksi, Komunikasi, dan Refleksi" ialah dihasilkannya RPP atau skenario pembelajaran yang berorientasi kegiatan MIKIR. Selanjutnya guru/peserta kegiatan tersebut dapat mengelola pembelajaran secara online (karena situasi pandemi) dalam menerapkan pembelajaran aktif tersebut.

Kegiatan PKM dilakukan dengan tahapan sebagaimana yang sudah sirencanakan pada bagian tiga laporan kegiatan ini. Adapun implementasinya adalah sebagai berikut:

Tabel 2. Tahapan Kegiatan PKM Pelatihan dan Pendampingan

\begin{tabular}{|c|c|c|c|}
\hline No & Tahapan & Kegiatan & Partisipasi Mitra \\
\hline 1 & Persiapan & $\begin{array}{l}\text { a) Observasi dan wawancara untuk analisis } \\
\text { permasalahan yang dialami guru dalam } \\
\text { pengelolaan pembelajaran secara daring. } \\
\text { b) Membangun komitmen bersama dengan } \\
\text { sekolah mitra. } \\
\text { c) Menentukan jadwal kegiatan, dan } \\
\text { d) Menyediakan segala keperluan sarana } \\
\text { dan prasarana dalam mendukunng } \\
\text { terlaksananya kegiatan pengabdian } \\
\text { dengan baik. }\end{array}$ & $\begin{array}{l}\text { Peserta pelatihan diberikan } \\
\text { materi mengenai pentingnya } \\
\text { pembelajaran aktif dalam } \\
\text { pembelajaran }\end{array}$ \\
\hline 2 & Pelaksanaan & $\begin{array}{l}\text { a) Memberikan sosialisasi } \\
\text { b) Melaksanakan pendampingan }\end{array}$ & $\begin{array}{l}\text { - Peserta dilatih melaksanakan } \\
\text { pembelajaran aktif, melalui } \\
\text { materi: } \\
\text { 1. Pembelajaran aktif } \\
\text { 2. Pengelolaan lingkungan } \\
\text { kelas } \\
\text { 3. Pengembangan Lembar } \\
\text { Kerja Siswa } \\
\text { 4. Pengembangan budaya } \\
\text { baca } \\
\text { 5. Praktik mengajar } \\
\text { 6. Rencana tindak lanjut }\end{array}$ \\
\hline 3 & $\begin{array}{l}\text { Evaluasi dan } \\
\text { Refleksi }\end{array}$ & $\begin{array}{l}\text { Berdasarkan masukan dari tim pengusul, } \\
\text { mitra kembali mengelola portal berdasarkan } \\
\text { arahan dari tersebut. }\end{array}$ & $\begin{array}{l}\text { Menghasilkan skenario } \\
\text { pembelajaran aktif }\end{array}$ \\
\hline 4 & Tindak Lanjut & $\begin{array}{l}\text { Semakin terampilnya guru pada sekolah } \\
\text { mitra dalam mengelola pembelajaran aktif } \\
\text { berbasis IT. }\end{array}$ & $\begin{array}{l}\text { Terus berkomitmen untuk } \\
\text { mengasah kemam-puan dalam } \\
\text { melakukan inovasi pembelajaran } \\
\text { dengan mengintegrasikan IT. }\end{array}$ \\
\hline
\end{tabular}

Pelaksanaan kegiatan pendampingan ini dilakukan dari tanggal 23 Juni sampai 05 Juli 2020 dengan dua tahapan yaitu sosialisasi dan pendampingan pembuatan scenario pembelajaran aktif berorientasi kegiatan MIKIR sebagaimana yang dijelaskan tabel di atas. Kegiatan sosialisasi pembelajaran aktif di masa pandemic, dilakukan dengan virtual zoom meeting. Kegiatan sosialisasi berlangsung selama 2 jam. Kegiatan dihadiri oleh 15 orang peserta guru dan 3 orang pelaksana kegaiatan. Kegiatan juga dihadiri oleh staff lembaga penelitian dan pengabdian UMSU.

Proses evaluasi akhir dilakukan dengan memberikan tugas mandiri kepada peserta untuk menyusun scenario pembelajaran. RPP yang dibuat disesuaikan dengan bidang 
keahlian/ mata pelajaran yang diampu masing-masing peserta. Pada proses pengerjaan tugas mandiri, dilakukan proses pendampingan oleh instruktur kepada peserta. Bagi peserta yang merasa kesulitan dan membutuhkan bimbingan tentang segala sesuatu yang berkaitan dengan pengerjaan tugas mandiri diperbolehkan untuk melakukan konsultasi dengan instruktur pelatihan.

Hasil dari tugas mandiri ini menjadi acuan bahwa peserta telah menguasai kompetensi yang diajarkan pada saat pelatihan. Dari hasil tugas mandiri, didapatkan hasil yang baik, dimana semua peserta dapat menyelesaikan pembuatan tes/ujian online sesuai dengan kompetensi yang dajarkan pada saat pelatihan. Adapun yang membedakan antara hasil satu peserta dengan hasil dari peserta lainnya adalah waktu pengerjaan, dimana ada beberapa peserta yang cepat menyelesaikan pengerjaan tugas mandiri, dan ada pula yang relatif lebih lama. Keseluruhan pendampingan menunjukkan bahwa peserta telah mampu menyusun scenario pembelajaran yang berorientasi kepada pembelajaran aktif MIKIR.

\section{SIMPULAN}

Berdasarkan hasil pelaksanaan Pelatihan dan Pendampingan Guru-Guru SD Muhammadiyah 12 Medan dan SD Muhammadiyah 13 Medan dalam Melaksanakan Pembelajaran Aktif Berorientasi MIKIR (Mengamati, Interaksi, Komunikasi, dan Refleksi yang telah dilakukan serta pembahasan pada bab sebelumnya, dapat ditarik kesimpulan sebagai berikut : 1) Kegiatan pelatihan dan pendampingan dalam rangka pelaksanaan kegiatan pengabdian masyarakat ini secara umum dapat dikatakan berhasil dengan indikator jumlah peserta yang mencapai terget serta keterlibatan peserta yang sangat antusias dan aktif. 2) Layanan konsultasi yang dilaksanakan setelah kegiatan pelatihan dan pendampingan dalam kegiatan pengabdian pada masyarakat ini tidak dimanfaatkan secara maksimal oleh kelompok masyarakat sasaran. Kesimpulan ini ditarik berdasarkan sedikitnya kegiatan konsultasi yang dilakukan, dan 3). Pendampingan pada sekolah dalam melaksanakan ujian online telah terlaksana dengan baik, meskipun dengan jumlah terbatas. Mitra juga berniat untuk melakukan kerjasama secara khusus dengan institusi (UMSU) dalam hal penerapan e-learning pembelajaran aktif berorientasi MIKIR.

\section{DAFTAR PUSTAKA}

Daryanto. (2012). Media Pembelajaran. Bandung: PT Sarana Tutorial Nurani Sejahtera (SATUNUSA). Hamid, M.S. (2011). Metode Edutainment: Menjadikan Siswa Kreatif dan Nyaman di Kelas. Yogyakarta: Diva Press 
Elfrianto, Ismail Saleh Nst \& Eko Febriansyah Siregar, Implementasi Pembelajaran Aktif Berorientasi Mikir

Lobo, Fridarlin Magda Noni Wuri. (2016). Pemanfaatan Schoology Untuk Meningkatkan Aktivitas Belajar Siswa (Studi Kasus: Sma Negeri 1 Tengaran). Diunduh pada 20 Juli 2018 http://repository.uksw.edu/ handle/123456789/10683

Palandi, J., (2017). Pengembangan Aplikasi Web E-Learning Untuk Pendidikan Anti Korupsi Menggunakan Moodle. JURNAL INOVTEK POLBENG - SERI INFORMATIKA, VOL. 2, NO. 2 , NOVEMBER 2017, hal 173-181.

Setiawan, D. (2014). Pendidikan Kewarganegaraan Berbasis Karakter melalui Penerapan Pendekatan Pembelajaran Aktif, Kreatif, Efektif dan Menyenangkan, Jurnal Pendidikan Ilmu-Ilmu Sosial, 6 (2): 6172.

Wahid, A, (2015). Pelatihan dan Penerapan E-Learning dan M-Learning Berbasis Moodle Bagi Guru Siswa Smk Persada dan Bajiminasa Makassar. Jurnal Inovasi dan Teknologi Pembelajaran, Volume 1, Nomor 2, April 2015, hlm. 102-107.

Yakob. M \& Sari. M. (2019). Peningkatan kemampuan Siswa SMP Membaca Puisi Dengan Metode Pembelajaran Aktif Kreatif dan Menyenangkan. Journal of Education, Humaniora and Social Sciences (JEHSS). 2 (1):93 - 103.

Yuhdi, A dan Amalia, N. (2018). Desain Media Pembelajaran Berbasis Daring Memanfaatkan Portal Schoology pada Pembelajaran Apresiasi Sastra. JURNAL Basastra Pendidikan Bahasa dan Sastra Unimed. Vol 7 (1) 2018 hal 14-22. 